International Review of Research in $\boldsymbol{O}$ pen and Distance Learning

Volume 10, Number 2.

ISSN: 1492-3831

April - 2009

Regional Focus Issue: Bridge over Troubled Waters Cengiz Hakan Aydin and Yoram EshetAlkalai, IRRODL Regional Editors for the Middle East

\title{
Are We There Yet? A Progress Report from Three Turkish University Pioneers in Distance Education and E-Learning
}

\author{
Colin Latchem \\ Open Learning Consultant, Australia \\ Nurettin Simsek and Ozlem Cakir Balta \\ Ankara University, Turkey \\ Orhan Torkul and I. Hakkı Cedimoglu \\ Sakarya University, Turkey
}

Alpaslan Altunkopru

Ahmet Yesevi University, Turkey

\begin{abstract}
The international literature provides little in-depth analysis of distance education and e-learning activities, achievements, and challenges in Turkish higher education other than the country's mega-university, Anadolu. This paper examines the development of, and lessons to be learned from, such undertakings by three pioneers - two regular state universities, Ankara University and Sakarya University, and the private, non-profit Turkish-Kazakhstan Ahmet Yesevi University. Drawing on the collective experience of the authors, the paper reaches some overall conclusions about embarking on distance education and e-learning, which may apply in other Turkish universities and similar economies.
\end{abstract}

\section{Introduction}

Turkey is a democratic secular developing nation of about 70,600,000 people ${ }^{1}$. Bridging two continents, it has a blend of Eastern and Western cultures. It links with the West through its membership of such organizations as the Council of Europe, the North Atlantic Treaty

\footnotetext{
${ }^{1}$ http://turkeyeconomy.blogspot.com/2008/01/turkey-population-statistics.html
} 
Organization (NATO), and the Organisation for Economic Co-operation and Development (OECD) and associate membership and candidature for full membership of the European Union (EU). As a Muslim-majority country, it also fosters close cultural, political, and economic ties with the Middle East and Central Asia. Its economy was originally agricultural; today, it is increasingly dominated by the industrial and service sectors.

Turkey's higher education system comprises 94 state and 35 private universities, plus a number of police and military academies and vocational colleges. The universities' faculties and four-year schools offer bachelor and graduate programs, and their two-year vocational schools offer prebachelor (associate) degree programs.

Turkey also has one of the world's mega-universities, Anadolu University, in the city of Eskişehir in central Anatolia. In 1981, when the Higher Education Council (YÖK) first authorized regular universities to move into distance education, the only institution to do so was Anadolu (Latchem, Özkul, Aydin, \& Mutlu, 2001). In 2008, Anadolu's Open Education Faculty had a total enrolment of 1.5 million students, about $40 \%$ of all university students and $99 \%$ of all distance education students in Turkey. Apart from some teacher training programs, Anadolu exercises no quotas in its courses and programs. Entry to Anadolu's two- and four-year programs is open to all Turkish and North Cyprus high school and vocational and technical high school leavers achieving a score of at least 160 in the Student Selection Examination (ÖSS), as opposed to the minimum of 185 required by the regular universities. As in the regular universities, examination requirements are waived for vocational and technical high school graduates continuing in their same fields of study.

In 2007, the Higher Education Council (YÖK) aimed for a $25 \%$ increase in the number of places in the regular universities. In the event, with just over 1.5 million school leavers applying for university places, 2008 saw a $27 \%$ increase, from 433,150 to 552,392. About one third of these students entered the regular universities' four-year degree programs, $29 \%$ enrolled in the twoyear programs, and almost $40 \%$ signed up for the two- and four-year programs offered by Anadolu University.

YÖK is keen to achieve greater access, equity, quality, and cost-effectiveness in higher education. Over $26 \%$ of the population is in the $0-14$ age group, most of the universities are in the wealthier west of the country, and the private universities have only a $5.7 \%$ share of the market. Former Vice-Rector of Anadolu University and now Member of YÖK, Ali Ekrem Özkul (2001) suggests that distance education provides a rational means of increasing capacity, maximizing resources, and realizing the nation's human resource potential. However, because of the conservative institutional cultures, cumbersome bureaucracy, under-funding, and high level of government control over expenditures, the regular universities have been slow to adapt to the changing demands and to the need to be more competitive (Mizikaci, 2006).

Distance education is still in its infancy in the Turkish higher education system (Usun, 2003). In 1956, Ankara University's Faculty of Law offered the country's first university correspondence course, designed for bank employees (Şimşek, 2005). During the 1990s, Firat University, Selcuk 
University, and a few other institutions began operating their own local television channels, and the Middle East Technical University, Bilkent University, Istanbul Bilgi University, and some other universities began teaching by videoconferencing. A number of universities are now introducing e-learning into their on-campus and off-campus programs, but there is a lack of instructional design expertise (Aydin, Mutlu, \& McIsaac, 2006), and the universities mostly produce digital versions of existing teaching materials rather than new and effective e-learning environments (Cebeci, 2004).

There is a lingering suspicion that technology-based mass education compromises educational quality, and YÖK has exercised caution towards distance education, requiring any university wishing to open, change, or close a distance or e-learning program to first seek its approval (Torkul, Sezer, \& Över, 2005; Karakuzu \& Karaman, 2006). However, YÖK is now more actively encouraging the universities to enter this field.

The international literature provides little in-depth analysis of distance education activities, achievements, and challenges in Turkish universities other than Anadolu. It is therefore considered timely to describe and analyse the work of three of the pioneering universities Ankara University, Sakarya University, and Ahmet Yesevi University - to see how their experiences might serve to inform universities in Turkey and similar economies contemplating moves into distance education.

\section{Ankara University}

Turkey's first state university, Ankara University, was founded in 1946. It has Faculties of Agriculture, Communication, Dental Medicine, Divinity, Educational Sciences, Engineering, Forestry, Health Sciences, Medicine, Pharmacy, Political Sciences, Science and Veterinary Medicine, as well as 13 technical training and vocational schools and 8 institutes. Also, it operates over 9 campuses.

Ankara University's Distance Education Centre, the Turkish acronym for which is ANKUZEM (see http://www.ankuzem.ankara.edu.tr), resulted from the Rectorate and a few academics and educational technologists recognizing the need to respond to student and employer demand for alternative forms of provision, to improve access and equity, and to apply new and more costeffective teaching measures across the various campuses. Following a pilot project, ANKUZEM was established in 2002 and a year later it began delivering distance and e-learning programs.

ANKUZEM's vision is to provide learner-centered blended learning enriched by the use of multimedia and individual or collaborative enquiry. It has employed a range of strategies reports, displays, seminars, examples of best practice, and research findings - to help change the institutional policies and culture and staff attitudes towards new forms of provision. It also provides staff training and support in instructional design, multimedia, and Web-based teaching and learning. 
ANKUKEM's director reports directly to the rector and is also answerable to an Academic Board and Board of Management. There are two assistant directors, one responsible for administration, finance, service delivery, and student affairs, and the other for design, production, and application. The other 11 employees are responsible for developing, maintaining, and updating courses and courseware as well as conducting research and managing the learning management system (LMS), staff development, enrolments, learner support, assignments, and examinations. The centre's main strength lies in the knowledge and experience of these staff members. Its main problem is the size of the staff relative to the ever-growing number of students and courses. ANKUKEM currently serves 1,190 distance education students, 940 at undergraduate level and 250 at certificate level. New programs planned for 2009-10 include associate degree programs in insurance studies and tourism and hotel management and master's programs in business studies and education, each with a target enrolment of 500, and a master's program in distance education with a target of 250 students.

ANKUZEM's $350 \mathrm{~m}^{2}$ studio, LMS, six servers, and state-of-the-art technologies are heavily employed in providing online teaching and learning, videoconferencing, interactive IP multicast via Turkey's National Research and Education Network, high-definition broadband-delivered streamed video, and interactive virtual classrooms for on- and off-campus students. ANKUZEM also uses videoconferencing and WebTV to link with other universities in Turkey, Japan, and South Korea.

ANKUZEM's first venture in distance learning was an off-campus version of the on-campus undergraduate theology program (İLITAM) relating Islamic cultural heritage to contemporary life. Using a mix of online content and chat, interactive video, and face-to-face methods, this program attracts male and female students in Turkey and 14 other countries. ANKUZEM now also provides a Conservation in Museums (ÖKOP) program for museum researchers, which currently has 21 enrolees, a Synchronous Medicine Education (STIP) associate degree program with an enrolment of 50, the European Computer Driving Licence (ECDL) program, which currently has 775 students, and a synchronously-delivered course on Korean economics for 30 students in the Faculty of Agriculture.

As with the on-campus programs, the students are selected on the basis of their high school achievement and Student Selection and Placement System (ÖSYM) grades. In 2008, about 25\% of the off-campus students were 25 years or younger, just under 50\% were in the 26-35 age group, about $25 \%$ were in the 36-45 age group, and a few were 46 or over. In the same year, $42 \%$ of the on-campus students were 25 and under, $42 \%$ were in the $26-35$ age group, $15 \%$ were in the $36-45$ age group, and again only a few were 46 or over. The distance students are predominately male and live in urban areas. About $75 \%$ have access, albeit sometimes restricted, to computers and the Internet. Fewer than $20 \%$ describe themselves as highly skilled in the technology (Şimşek, 2006).

Upon enroling, the students are issued with ID numbers, which enable them to access the online materials and support services, CDs, videos, study guides, etc. Orientation, instruction, tutoring, assessment, and feedback are provided through a mix of online and face-to-face methods. The 
students can join virtual academic and technical forums and coffee shops and exchange ideas with their tutors and peers by email. They can also attend face-to-face classes at centres in İstanbul, Bursa, Ankara, Erzurum, Sivas, Adana, İzmir, Isparta, Sanliurfa, Samsun, or, in the case of Turkish citizens, in Cologne, Germany. The courses, examinations, and awards are identical to the on-campus programs. There is no indication of the mode of study on the awards but even if they do find this out, employers appear happy to accept graduates who studied at a distance.

In 2005-2008, the pass rates for the two-year distance education programs were $85-90 \%$ and the drop-out rate was $0.4 \%$. These figures may be exceptional - the time-frame is limited and the number of graduates is small - but they certainly compare well with the experience of US, European, Asian, and Turkish distance teaching universities (Şimşek, 2006; Şimşek \& Parlak, 2005). The Centre's staff members feel that their careful planning, concern for students' needs, and training and support for staff are paying off.

One of ANKUZEM's aims is cost-effectiveness. It has been found that the fees from the two-year İLITAM program are sufficient to meet all the program development, delivery, and teaching costs, that the cost of the program is significantly lower than the on-campus version, and that the overall cost benefit to the university is $298 \%$.

ANKUZEM offers services to other Turkish universities. It is a member of the 45-institution National Open Course Materials Consortium founded by the Turkish Academy of Sciences (TÜBA), having earlier pioneered the sharing of courseware with the Middle East Technical University. Such work is strongly supported by the Senate because it makes the faculties and their courses better known and demonstrates the university's willingness to share its knowledge and resources with less well-resourced institutions and the general public.

ANKUZEM is also involved in a number of international open and distance learning projects. It is a member of the European Distance Education Network (EDEN) and has bilateral agreements with the UK Open University, Bemidji State University in the US, and Modern University for the Humanities in Russia.

As well as increasing the range of programs on offer, ANKUZEM's future plans include achieving the status of a university institute in acknowledgement of its research and its developmental and service role.

\section{Sakarya University}

After opening in 1970 as the School (later State Academy) of Engineering and Architecture and operating between 1982 and 1992 as a faculty of Istanbul Technical University, Sakarya University finally became a university in its own right in 1992. It has Faculties of Education, Arts and Humanities, Fine Arts, Economics and Administrative Sciences, Theology, Engineering, and Technical Education; Schools of Healthcare and Physical Education and Sports; Graduate Schools of Natural Sciences and Social Sciences; and 10 Vocational Schools including the Distance Education Vocational School of Adapazarı. In 2009, the university had 45,576 students 
- 25,273 in its undergraduate, master's, and doctoral programs and 20,303 in its two-year vocational school programs.

In 2005, the Department of Informatics established the Distance Learning Research and Development Centre (see http://www.uzem.sakarya.edu.tr) with the aim of providing online programs for the university and other public and private organizations and conducting research and development in this field. A number of factors have contributed to this initiative. Sakarya University has made considerable investments in, and contributes significantly to, the development and application of information and communications technology (ICT) in Turkey. In 2001, it collaborated with the Ministry of Education in mounting Turkey's first International Educational Technology Conference and Fair, and it also hosted this event in 2002, 2003, and 2004. The editor of the Turkish Online Journal of Educational Technology (see http://www.tojet.net/) is the coordinator of the Faculty of Education and the journal operates from this base. Senior management and some of the academic departments have been strongly supportive of the university's moves into distance education and e-learning, recognizing the potential to increase participation rates, provide lifelong learning, and improve the quality, scope, and cost-effectiveness of on- and off-campus teaching and learning.

The Centre offers four-year degree programs, two-year vocational school degree programs, and postgraduate degree programs through distance education. In 2009, 50 students were enroled in each of the four-year degree programs in computer engineering, industrial engineering, and human resource management; 460 postgraduate students were taking the e-MBA program; 27 were in the information technology master's program; and 14 were in the engineering management master's program. Online enrolments in the vocational high school courses were very much higher, with 1,557 studying computer technologies and programming, 1,052 information management, 1,367 mechatronics, 1,262 industrial electronics, and 1,133 business studies. Most of the vocational students are aged between 17 and 20, but these courses also attract some older students who are already in jobs.

The Centre collaborates with the Ministry of Health in a Family Doctor Distance Learning Project in which the Ministry's educational materials are being converted into multimedia courseware for Internet delivery to over 25,000 doctors nationwide. The Centre also runs online certificate programs in ICT for the University and the Ministry of National Education. It is a test centre for the ECDL programs. It develops and provides Internet-based or blended learning courses in ICT for on-campus students in social sciences and natural sciences. It also runs online and face-to-face summer schools in ICT, the most recent attracting just under 5,000 students.

The University's Academic Committee and Accreditation Committee determine which programs the Centre may provide through distance and e-learning and which lecturers should participate in these. The Centre's staff comprises a director, an assistant director, 18 academic staff, 4 technical staff, and 12 administrative and clerical staff. It is organized into five operational units: Content Development, System and Database Management, Organizational Planning, Standards and Procedures, and Research and Development. 
Course and courseware development follows the Analysis-Design-Development-Implementation and-Evaluation (ADDIE) model (Torkul, Över, Göksu, \& Selvi, 2005). The course content is developed by the teaching staff, the courseware is digitized then converted into multimedia form and transferred to the Internet environment by the Centre's instructional/Web designers, and the outcomes are monitored by the Centre's research and evaluation personnel. The Centre is also responsible for the provision of technical and learner support, marketing the distance education programs, and training and supporting academic staff in instructional design and distance and online teaching and learning.

The courses and programs are delivered through various combinations of online videoconferencing, asynchronous Web-based learning and face-to-face interaction, according to the level of study. The certificate programs are wholly Web-based. Ninety percent of the vocational school programs are asynchronously online supplemented by face-to-face tutorials and practical work. The four-year programs are taught through blended learning, $70 \%$ being online and $30 \%$ classroom-based. The postgraduate programs are entirely ICT-based, $80 \%$ via the Web and $20 \%$ by videoconferencing.

Assessment and examinations are conducted through a mix of multiple-choice testing, essay-type answers, and practical work. The final awards indicate the mode of study but there is no evidence to suggest that employers think any less of these graduates.

The Centre's staff research and act as advocates for e-learning (Torkul, Över, Göksu, \& Selvi, 2004; Torkul, Sezer, \& Över, 2005). One recent research project, the Sakarya UniversityAdvancity Academic LMS Project, enabled the University's faculties, graduate schools, and vocational schools to engage more cost-effectively in distance education and e-learning delivery, tracking, and evaluation. This work grew out of the Centre's earlier SAUIDO Server Optimization and Exam Module Project for the State Planning Organization, which investigated the infrastructure, operations, performance, and effects of LMSs, and the Server University Project in which Sakarya acted as a server university for other Turkish universities. Lessons learned in on- and off-campus applications of the Internet and multimedia, development of AICC and SCORM compliant courseware, and LMS operation are shared with public and private organizations.

The Centre is involved in planning the Sakarya Technology Park, which will research the potential of technology for agricultural and industrial development, e-commerce, and e-education and training. Other projects have included the Internet-based SAULMS Education Management System Software Project, the Sakarya University-IBM Content Development Project, which provided blended training in e-learning design and development for staff at Yildiz Technical University in Istanbul, and a Global English IDO Certification Pilot Project run in collaboration with the Ministry of Education, which used online methods to teach, test, and examine teachers in Ankara and Sakarya in English as a Second Language.

The Centre's operational, program development, and delivery costs are partly met by the students' fees and partly through projects undertaken for the public and private sectors. Some of 
the academic departments still show little interest in distance and technology-based learning and some of the teaching staff are still concerned that large-scale technology-delivered education may compromise quality. However, the Centre's experience and influence is growing and, as at Ankara University, the main challenge is maintaining quality while serving the growing number of students.

\section{Ahmet Yesevi University}

Ahmet Yesevi University (see http:// www.yesevi.edu.tr) is a very different kind of institution. Named for the $12^{\text {th }}$ century Sufi mystic and poet famed throughout the Turkic-speaking world, this partner university was established in 1992 by the Turkish and Kazakhstan Republics with the aim of connecting the Turkish speaking countries, including some former Soviet states. Its constitution stipulates that the rector must be Kazakh, its vice-rector Turkish, and the Board of Trustees comprise four Kazakh and four Turkish members.

The University's main campus in the city of Türkistan in southern Kazakhstan houses the Faculties of Economics, History and Education, Foreign Languages, Law, Information Technology and Engineering, Medicine, Science, and Sports and Arts. Its other campus in Kazakhstan is in Kentav, with Faculties of Education and Engineering. Students may apply from any Turkish speaking country and Ahmet Yesevi University diplomas and degrees have the same status and confer the same rights as those of other universities in Kazakhstan or Turkey.

The University's first use of videoconferencing was for conducting meetings between Türkistan and the Ankara office in the 1990s. Its first educational application of the technology was teaching graduate programs in business and tourism programs between Türkistan and Gazi University in Ankara and Selçuk University in Konya.

In 2001, the Board of Trustees decided to establish the Internet-based Distance Education Department or TÜRTEP (Distance Education Program Using Turkish Language). It was envisaged that using Internet technologies would help to achieve the university's ideals of connecting Turkish-speaking countries and, by capitalizing on the knowledge and skills of Turkish and Kazakh academics, attract mature-aged learners already in jobs and enable the university to collaborate with other universities, nationally and internationally.

The decision was taken to base TÜRTEP in İstanbul because the infrastructure in Kazakhstan was judged to be inadequate to the task. Those who now form TÜRTEP's senior management team established the technological feasibility of the scheme with ICT experts. However, because they were still largely unfamiliar with the educational applications of the technology, TÜRTEP was not officially recognized by YÖK, and distance education was regarded with some suspicion by academe and the wider community, the outcomes were somewhat unpredictable. Despite these concerns, TÜRTEP went ahead and in 2002, it enroled its first students, most of whom were in Turkey and Kazakhstan, but a few of whom were in Azerbaijan, Bulgaria, Bosnia-Herzegovnia, Uzbekistan, Kyrgyzstan, Turkmenistan, Iraq, and Ukraine. 
Unlike the Sakarya and Ankara distance education centres, TÜRTEP may be classified as a virtual institution. It is physically separated from its parent institution, it has no on-campus facilities, and no students cross the threshold of what is essentially a suburban office block. And unlike the main university in Kazakhstan, which is a state institution, TÜRTEP is private and non-profit.

The personnel in TÜRTEP's Istanbul offices comprise a chair, a vice-chair academic, a vice-chair technical, a number of part-time departmental chairs, 6 part-time online content developers and instructional designers, three educational support staff, three technical support staff, two student affairs officers, three examinations office personnel, one driver, and a factotum. The administrative personnel at the Ankara office also provide occasional support for TÜRTEP.

In 2008, TÜRTEP had 2,210 enrolees in its vocational school computer programming program, undergraduate programs in computer engineering, industrial engineering, management information systems, hospital management, educational management, and regional management, and master's programs in computer engineering, management information systems, and business administration, all of which have their on-campus counterparts in Kazakhstan. The majority of the students are mature-aged with $37 \%$ in the $20-30$ age group, 50\% in the 30-40 group, and about $12 \%$ in the 40 or over age group.

Like Ankara and Sakarya Universities, TÜRTEP requires its students to have satisfactory high school and ÖSS scores. The course fees are slightly higher than in the state universities but slightly lower than in the other private universities. Most of the students have daytime jobs. Some opt for study through TÜRTEP because they cannot gain entry to the regular universities but most do so for reasons of work or family circumstances.

The course content is commissioned from outside academics, who are paid for the Internet usage rights of their material as well as their teaching. These lecturers are recruited for their computer skills as well as their subject expertise, so most of them are quite capable of creating their own PowerPoint presentations. They are given training in using the LMS and managing virtual classes but they lack experience in instructional design, so the courseware is improved through instructional design and enriched with animations, multimedia, simulations, and virtual labs by the course developers and instructional designers. Before their release to the students, the courses and courseware must then be approved by the department chairs and Academic Evaluation Committee. The online teaching of the 120 online lecturers, who are recruited from 30 universities and the private sector, is also subject to monitoring by the Academic Evaluation Committee, departmental chairs, and educational and technical support personnel.

TÜRTEP's programs are wholly online. To allow for the fact that the students have day jobs, the online classes start at 6:00 pm on weekdays and run for six hours. They begin with 45 minutes' synchronous instruction with the lecturers teaching from their homes using Adobe Acrobat Connect, webcams, PowerPoint, electronic whiteboards and digital tablets. The students, who are usually also home-based, interact by means of webcams, microphones, digital tablets, and chat. The remaining five and one-quarter hours of class time are asynchronous and largely postings- 
based. The students can access the courseware $24 / 7$ but it is found that they attach more importance to the live, synchronous elements of these courses than LMS-served content because they feel that these are more up-to-date and motivational.

Assessment is based upon course work, examination, practical work, and participation and performance in the virtual classes. Out of a maximum of 100 points in the semester grading, performance in the mid-semester online exams accounts for 60 points, course content visits and virtual class attendance and performance 25 points, and assignment work 15 points (students are required to complete at least two assignments per semester). These 100 points represent 30 percent of the semester grading. The other $70 \%$ is based upon the end-of-semester examinations, which students sit at centres in Ankara, Istanbul, and Türkistan. Assessment is rigorous and upon graduating, the awards make no mention of the students having studied at a distance.

Providing support for the learners requires real commitment from the staff. Because the classes are run in the evenings, like the students, the educational and technical support personnel operate from home. Being on call at any time between 6:00 p.m. and midnight, they can put in many more hours than they are actually paid for. The student affairs officers also come under pressure at the start of semesters because they are so few. The examinations personnel can also be pressured at exam times.

Under the previous YÖK administration, despite the lecturers being from accredited institutions and the courses and programs being based upon those recognized in the parent organization, TÜRTEP experienced some problems in program accreditation. However, these are now being resolved.

TÜRTEP plans to enrol an additional 1,000 students in new vocational and master's programs in mechatronics, industrial electronics, industrial automation, and TV and radio broadcasting. It also plans not only to offer these programs in Turkish but through RUSDEP or Internet Based Education in Russian Language and KAZTEP or Internet Based Education in Kazakh Language. The ultimate aim is to achieve an enrolment of 20,000 students.

It has taken 5-6 years to recoup the costs of establishing TÜRTEP. But now the fees from the vocational school, undergraduate, and graduate courses are sufficient not only to meet the costs of the building, services, staff, Internet courseware usage rights, and the part-time online lecturers (who are paid a fixed rate per semester plus an extra payment for every additional 20 students) but also to continually upgrade technology and services and recently to acquire new premises.

TÜRTEP's distance education programs are based upon the recognized programs of the parent institution; the curricula are reviewed every three years by the academic departments in Kazakhstan and TÜRTEP's departmental chairs; the qualifications gained have the same status as the equivalent on-campus programs; and employers express satisfaction with the courses and graduates. TÜRTEP is able to plan, budget, and operate more freely than the regular universities with their limited budgets and many demands on their resources and, unlike the for-profit private universities, does not need to be profit-driven. It can hire its lecturers from any university or the 
private sector on a semester basis and terminate contracts in the event of any decrease in student demand or unsatisfactory performance.

The challenges to be faced are the lecturers and support staff being largely self-taught, the heavy workloads, and the fact that while Turkish students have access to broadband, most of the students in the other countries are limited to dial-up.

\section{Conclusions}

Drawing on the collective experience of the authors, it is possible to arrive at some conclusions about distance education in the Ankara, Sakarya, and Ahmet Yesevi Universities, which may help others embarking on similar journeys.

The three universities' distance education provision, instructional design, staff development, research, and sharing of experience and resources are having an impact both in the institutions and the higher education system. They are shown to be responsive to changing stakeholder expectations and are willing to take risks and operate in different roles and spheres. Also, they compensate for the shortage of on-campus places, make existing courses more widely and costeffectively available, provide new courses in innovative ways, and provide courses and programs of the same quality as those on campus.

The majority of the distance education students are aged 26-45, with around 50\% in the 26-35 age group, indicating a strong demand from employees and older learners keen to improve their qualifications.

As the World Bank cautions, the problem of acute competition for university entrance in Turkey cannot be solved by simple expansion. Attempting too much too quickly will result in poor quality programs and services and over-stretched staff and resources. Ensuring the quality and reputation of institutions must take precedence over hasty and unlimited expansion (Hatakenaka, 2006).

Quality distance education and e-learning depends upon support from senior management, cultural change in institutions, careful planning and budgeting, quality in the LMSs and ICT, adequate training, support and time-release for teaching staff, and experienced instructional design and ICT support personnel.

Applications of ICT must take account of the distance learners' needs and circumstances, for example, their competence with ICT and access to broadband or dial-up. Age, gender, and educational ability also influence students' attitudes towards distance and e-learning. Researching 800 distance learners at the Vocational School of Adapazari of Sakarya University, Tekinarslan (2008) found that male students were significantly more positively inclined towards online learning than females, that mature-aged learners with family and work responsibilities were more appreciative of online learning, and that learners with lower grades were more negative towards distance education. 
Usun (2004) suggests that cultural factors can lead Turkish distance learners to experience difficulties with independent learning and unstructured learning environments. The roots of Turkish education lie in an oral tradition, the use of rote learning, and the sacredness of the text. Turkey's traditional value systems include loyalty, respect for authority, community understanding, close interpersonal relationships, and uncertainty avoidance. Turkish people tend to express themselves in practical terms rather than abstractions and, as Sever (2009) observes, like all Mediterranean peoples, they enjoy conversational flow. Inquiring into Turkish high school pupils' awareness and expectations of distance and e-learning, Inal, Karakus, and Cagiltay (2008) found that, despite their familiarity with ICT, the majority would not opt for wholly distance education programs because they would miss the face-to-face instruction and social climate of the classroom and would rather experience the university lifestyle at first-hand. These factors need to be accommodated in the instructional design, teaching, and uses of technology. The off-campus students need to be helped to feel that they are part of a university and members of a learning community. This explains why all three universities make far greater use of videoconferencing than most Western universities and why Ankara University and Sakarya University combine faceto-face and online methods in their undergraduate programs. These approaches ensure a high level of teacher presence and social presence.

So, are we there yet? No, the journey is long. But the way ahead is clear. 


\section{References}

Aydin, C.H., Mutlu, M.E., \& McIsaac, M.S. (2006). Integrating computer-supported learning into traditional distance courses. In F. M. M. Neto \& F. V. Brasileiro (Eds.), Advances in computer-supported courses (pp. 97-121). Hershey, PA: Information Science Publishing, IdeaGroup Inc.

Cebeci, Z. (2004). Türkiye Ulusal E-üniversitesi İçin Bir Model Çalışması, Çukurova Üniversitesi, Sosyal Bilimler Enstitüsü Dergisi, Cilt 13, Sayı 2. Retrieved February 25, 2009, from http://sosyalbilimler.cukurova.edu.tr/dergi.asp?q=Zeynel\&dosya=151

Cukadar, S. (2003, June). Library services for the electronic MBA students at Istanbul Biligi University. Paper presented at the $24^{\text {th }}$ Conference of the International Association of Technolical University Libraries, Middle Eastern Technical University. Retrieved February 25, 2009, from http://www.iatul.org/doclibrary/public/Conf_Proceedings/2003/CUKADAR_fulltext.pdf

Demiray, U. \& McIsaac, M.S. (1993). Ten years of distance education in Turkey. In B. Scriven, R. Lundin, \& Y. Ryan (Eds.), Distance education for the twenty-first century (pp. 403406). Oslo, Norway: International Council for Distance Education.

Hatakenaka, S. (2006). Higher education in Turkey for 21st century: Size and composition. World Bank. Retrieved February 25, 2009, from http://siteresources.worldbank.org/EXTECAREGTOPEDUCATION/Resources/4446071192636551820/S._Hatakenakas_report_on_Higher_Education_in_Turkey_for_21st_Ce ntury_Nov_2006.pdf

Inal, Y., Karakus, T. \& Cagiltay, K. (2008). Turkish high school students' considerations, expectation and awareness on distance education. Turkish Online Journal of Distance Education, 9(4). Retrieved February 25, 2009, from http://tojde.anadolu.edu.tr/tojde32/index.htm

Karakuzu, M. \& Karaman, S. (2006). Examining major instructional design models proposed for distance education in respect to their adaptability to Turkish higher education system. Proceedings of the $2^{\text {nd }}$ International Open and Distance Learning Symposium, Anadolu University, 473-488.

Latchem, C., Özkul, A.E., Aydin, C.H., \& Mutlu, M.E. (2001). The open education system, Anadolu University, Turkey: E-transformation in a mega-university. Open Learning, 21(3), 221-235.

Mizikaci, F. (2006). Monographs on higher education: Higher education in Turkey. Budapest: UNESCO European Centre for Higher Education. Retrieved February 25, 2009, from http://www.cepes.ro/publications/pdf/turkey.pdf. 
Özkul, E. (2001). Anadolu University distance education system from emergence to 21st Century. Turkish Online Journal of Distance Education, 2(1). Retrieved February 25, 2009, from http://tojde.anadolu.edu.tr/

Sever, N. S. (2009). The effectiveness on online and offline word of mouth messages on traditional course choice at tertiary level. Turkish Online Journal of Distance Education, 10(1). Retrieved February 25, 2009, from http://tojde.anadolu.edu.tr/

Şimşek, A. (2005). Distance education - public policy and practice in higher education: the case of Türkiye. Brazilian Review of Open and Distance Learning, 3(1) Retrieved February 25, 2009, from http://www.abed.org.br/publique/cgi/cgilua.exe/sys/start.htm?tpl=home\&UserActiveTem plate $=2$ ing

Şimşek, N. (2006, September). Quality of distance education: A case from Ankara University. Paper presented at the Conference on Transnational Cooperation in Distance and Blended Education, Ankara, Turkey.

Şimşek, N. \& Parlak, O. (2005, June). The variables which affect the student satisfaction in internet based education. Paper presented at IADIS International Conference e-Society, Quawra, Malta.

Tekinarslan, E. (2008). Attitudes of Turkish distance learners toward Internet-based learning: An investigation depending on demographical characteristics. Turkish Online Journal of Distance Education, 9(1). Retrieved February 25, 2009, from http://tojde.anadolu.edu.tr/tojde29/index.htm

Torkul, O., Över, T., Göksu, A. \& Selvi, İ.H. (2004). Information society transformation centers in education. Presentation at the Fourth International Symposium on Educational Technology, Sakarya, Turkey. (Turkish)

Torkul, O., Sezer, C. \& Över, T. (2005). Determination of information requirements in Internetbased education systems. Turkish Online Journal of Educational Technology, 4(1), 1937. (Turkish)

Usun, S. (2003). Educational uses of Internet in the world and Turkey: A comparative review. Turkish Online Journal of Distance Education, 4(3). Retrieved February 25, 2009, from http://tojde.anadolu.edu.tr/tojde11/index.htm 


\title{
THE AUTHORS
}

Colin Latchem, Open learning consultant, 2 Sherwood Road, Perth, Western Australia Email: clatchem@iinet.net.au

Assoc. Prof. Dr. Nurettin Simsek, Director of the Distance Education Centre, Ankara University Tandogan Campus, Tandoğan, Ankara,Turkey

Email: nsimsek@ankara.edu.tr

Dr. Ozlem Cakir Balta, Instructor, Faculty of Educational Sciences, Ankara University, 06590 Cebeci, Ankara, Turkey

Email: Ozlem.Cakir.Balta@education.ankara.edu.tr

Prof. Dr. Orhan Torkul, Director of Distance Education Research and Development Centre 54187 Esentepe-Campus, Sakarya, Turkey.

Email: torkul@sakarya.edu.tr

Prof. Dr. I. Hakkı Cedimoglu, Distance Education Research and Development Centre 54187 Esentepe-Campus, Sakarya, Turkey.

Email: cedim@sakarya.edu.tr

\author{
Alpaslan Altunköprü \\ Instructional Technologist \\ Ahmet Yesevi University, Istanbul \\ altunkopru@yesevi.edu.tr
}

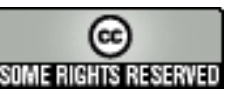

